\title{
The fish community of the Sorocaba River Basin in different habitats (State of São Paulo, Brazil)
}

\author{
Smith, WS. ${ }^{\text {a*, }}$ Petrere Jr., M. ${ }^{\mathrm{b} *}$ and Barrella, $W^{\mathrm{c}}$ \\ ${ }^{a}$ Universidade Paulista - UNIP, \\ Rua Antonio Adade, 67, apt. 2, pq. Campolim, CEP 18048-060, Sorocaba, SP, Brazil \\ ${ }^{\mathrm{b}}$ Departamento de Ecologia, Universidade Estadual Paulista - UNESP, \\ Av. 24 A, 1515, Bela Vista, CEP 13506-900, Rio Claro, SP, Brazil \\ 'Departamento de Ciências do Ambiente, Pontifícia Universidade Católica - PUC-SP, \\ Praça Dr. José Ermirio de Moares, 290, Jd. Vergueiro, CEP 18030-095, Sorocaba, SP, Brazil \\ *e-mail: welber_smith@uol.com.br, mpetrere@rc.unesp.br \\ Received April 3, 2008 - Accepted August 8, 2008 - Distributed November 30, 2009
}

(With 6 figures)

\begin{abstract}
A fish assemblage study was accomplished in different habitats of the Sorocaba River Basin. Fish were caught with gillnets, were weighed (weight total $-\mathrm{g}$ ) and measured (standard length $-\mathrm{mm}$ ). Several abiotic variables of selected sampling sites were measured in order to characterise their habitats in order to attempt establishing correlations with fish community traits. Fish numbers per species were adjusted to the lognormal and logseries species/abundance models The fish community totaled 38 species, distributed in 28 genera, 14 families and 4 orders. Diversity was calculated both in number and in weight and both presented higher values in better preserved sites. We did not detect any statistical differences between dry and rainy seasons. We also concluded that the abundance distribution was not influenced by abiotic variables.
\end{abstract}

Keywords: fish fauna, community dynamics, diversity, Sorocaba River.

\section{As comunidades de peixes da bacia do Rio Sorocaba, Estado de São Paulo, Brasil em diferentes hábitats (São Paulo, Brasil)}

\begin{abstract}
Resumo
Foi realizado um estudo das assembleias de peixes em diferentes ambientes aquáticos da bacia do Rio Sorocaba, São Paulo, Brasil. As espécies foram coletadas com redes de espera, sendo posteriormente identificadas. Foram obtidos dados relativos à abundância das espécies, pesos e comprimentos padrões, além de inúmeras variáveis abióticas das estações de amostragem para caracterização dos ambientes e correlação com a comunidade de peixes. A comunidade foi composta por 38 espécies de peixes, distribuídas em 28 gêneros, 14 famílias e 4 ordens. A comunidade de peixes se ajustou aos modelos lognormal e logsérie, característicos de comunidades com grandes riquezas e complexas, com múltiplas dimensões de nicho e superposição. A diversidade numérica apresentou maiores valores em estações mais preservadas, enquanto que para a diversidade em peso os maiores valores foram encontrados em locais mais preservados e também nos represamentos. Não foi detectada diferença nas diversidades entre as épocas seca e chuvosa. Para a comunidade de peixes da bacia do rio Sorocaba, a distribuição das abundâncias não foi influenciada pelas variáveis abióticas obtidas, devendo ser influenciadas pela estrutura do hábitat, não avaliada pelo presente trabalho.
\end{abstract}

Palavras-chave: ictiofauna, dinâmica da comunidade, diversidade, Rio Sorocaba.

\section{Introduction}

Tropical river basins are formed by different types of habitats where fish are adapted. As a result of the complex abiotic interactions among these habitats (e.g. river channel, floodplain lakes, marginal lagoons, reservoir), the biota is itself influenced by these interactions, as for instance, the interactions between marginal lagoons and the river channel, the complex ecotone landwater (Welcomme, 1979; Moring et al., 1985; Lowe-

McConnell, 1987; Godoy, 1995; Smith and Barrella, 2000). Especially in rivers, many concepts were developed, aiming to understand the relationships between their dynamics and the living community.

Among these we can mention the river continuum (Vannote et al., 1980), the flood pulse (Junk et al., 1989), the four dimensions concept (Ward and Stanford, 1989) and the mosaic of habitats concept (Pringle et al., 1988). 
In spite of the fact that each concept may present positive and negative points, their combined adoption appears to help understand the many events that take place in tropical and subtropical river basins.

Many papers focus on the fish community, in different aquatic ecosystems such as rivers and reservoirs. Among these the following stand out: Paraná River Basin, Godoy (1975); Caramaschi (1986); Castro and Arcifa (1987); Barrella and Petrere (1994), Barrella (1998); Uieda (1995) and Smith (1999).

But few focus on the basin as a whole. This approach is very important, because the continental aquatic ecosystems are impacted by anthropic actions such as industrial and domestic sewage, deforestation, river bed sand extraction, siltation, dams and alien species introduction, modifying the pristine diversity and aquatic habitat structures (White, 1972; Odum, 1985; Welcomme, 1985; Schreck and Moyle, 1995; Johnson et al., 1995; Camargo et al., 1995). These impacts occur throughout the drainage system. The objective of this paper is to to characterise the Sorocaba river basin fish community, in different habitats using the most usual indicators of community ecology such as richness, dominance and species diversity.

\section{Material and Methods}

The Sorocaba river basin is located in the state of São Paulo, with a drainage area of $5.269 \mathrm{~km}^{2}$ including 18 municipal districts (Smith, 2003). The river network is constituted by Rio Sorocaba, and its headstreams, rivers Sorocamirim and Sorocabuçu and the rivers Tatuí, Sarapuí, Pirajibu, Ipanema and Sarapuí as their main tributaries (Smith, 2003). About 25\% of the basin is still covered by natural forest, $4.5 \%$ with "cerrados" (savannahs) and "cerradões", 7.5\% of reforested area, 32.5\% of pasture and several crops like corn and sugarcane are predominant (São Paulo, 1990). There are other multiple uses, such as urban and industrial ones.

The fish sampling program was realised in 13 sampling sites in the Sorocaba river basin during the dry and wet seasons (Figure 1). Fish were caught with two gillnet batteries each including 8 nets $10 \mathrm{~m}$ long and $1.5 \mathrm{~m}$ high, with different sizes of meshes $(3,4,5,6,7,8,10$ and $12 \mathrm{~cm}$ opposite knots). The fish were measured (standard length-mm) and weighed (total weight - g) fixed in $10 \%$ formalin and preserved in alcohol $70 \%$. Later they were identified using proper identification keys (Britski, 1972; Britski et al., 1984; Garutti and Britski, 2000).

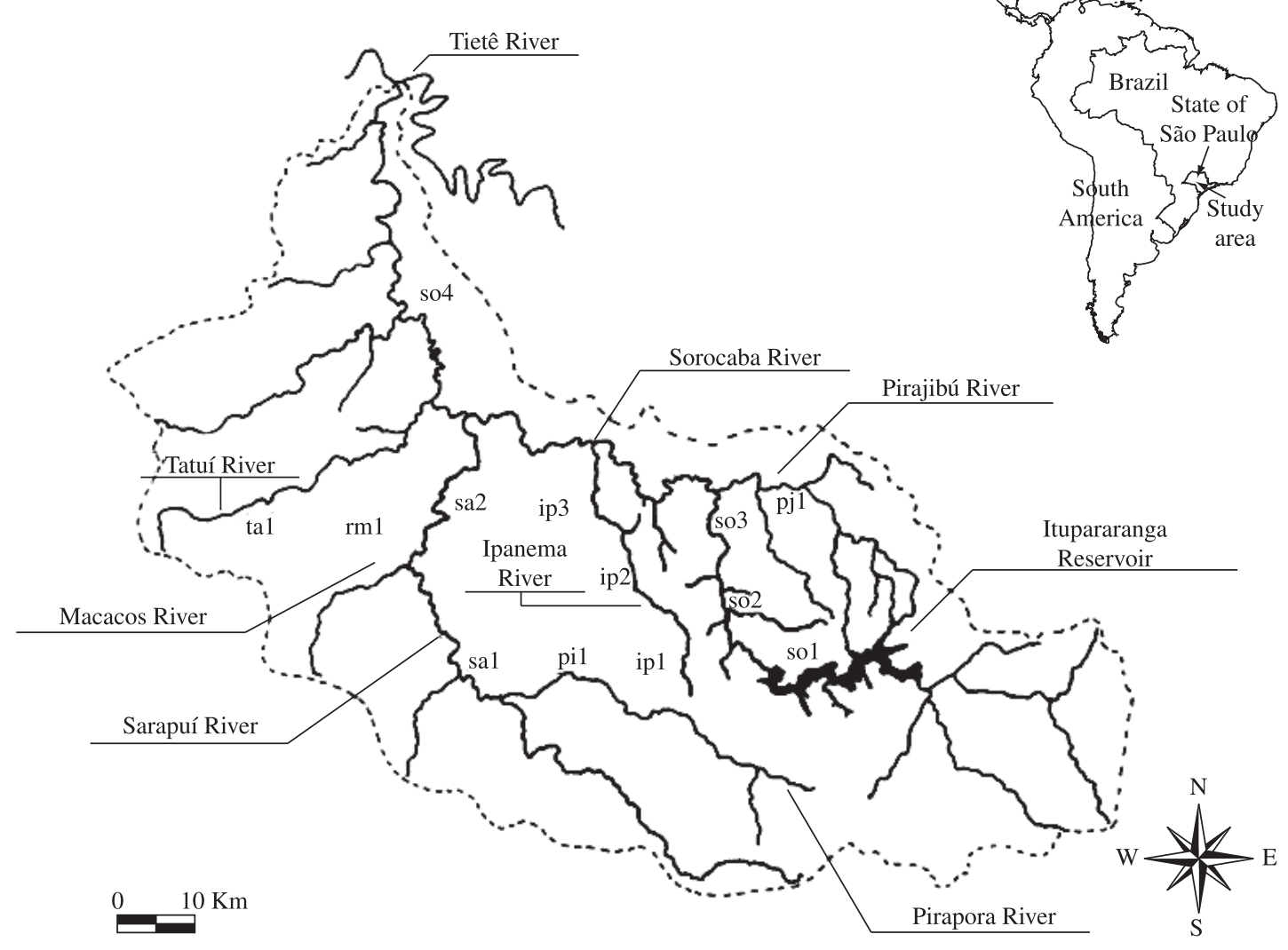

Figure 1. Sample sites in the Sorocaba river basin, SP, Brazil. 
Identification was later confirmed by Prof. Dr. Heraldo Britski of the Museu de Zoologia da Universidade de São Paulo (MZUSP).

The fish community was characterised according to Odum (1985), Magurran (1988) and Krebs (1989), through species richness estimated by the "jackknife" method. The Whittaker plot guided us in deciding about the most appropriate species-abundance model fitting (geometric series, logarithmic series, truncated lognormal and broken stick model). Diversity was measured using the Shannon-Wiener index $\left(\mathrm{H}^{\prime}\right)$ using natural logarithms.

Data analysis was carried out using univariate and multivariate techniques, as i) paired $t$-tests between the diversity of Shannon ( $\left.\mathrm{H}^{\prime}\right)$ calculated in number $\left(\mathrm{H}^{\prime}{ }_{\mathrm{N}}\right)$ as in weight $\left(\mathrm{H}_{\mathrm{w}}{ }_{\mathrm{W}}\right)$; the calculation of the Pearson correlation coefficient between the dry and rainy season for $\left(\mathrm{H}^{\prime}{ }_{\mathrm{N}}\right.$ and $\mathrm{H}_{\mathrm{W}}$ ); ii) cluster analysis and PCA and Mantel tests were the multivariate techniques adopted, according to Sneath and Sokal (1973), Manly (1986) and Digby and Kempton
(1987). Cluster analysis was used to classify the sampling sites using fish species abundance as indicators. The distance was measured by the Morisita-Horn index and the link function was the UPGMA. A dendrogram was drawn calculating the cophenetic coefficient of correlation in order to evaluate data distortion (Romesberg, 1984). Values of $r_{\text {coph }}<0.80$ would indicate distortion. Using the distance (based on the original physical and chemical variables published in Smith and Petrere Jr. (2000)) and similarity matrices obtained by the clustering algorithm, the test of Mantel was accomplished (Sneath and Sokal, 1973) in order to verify if there is significant correlation between the two data matrices (Manly, 1986).

\section{Results}

\subsection{The fish community}

The fish community presented 38 species (Table 1 ), distributed in 28 genera, 4 orders and 14 families of tel-

Table 1. Codes used to define species, common names and their respective scientific names; abundance of individuals (N); mean standard length (SL, mm) in cm; total weight (TW, g), and individuals mean weight (W, g) for the whole sample

\begin{tabular}{|c|c|c|c|c|c|c|}
\hline Code & Vulgar names & Scientific names & $\mathbf{N}$ & $\mathbf{S L}$ & TW & $\mathbf{W}$ \\
\hline $\mathrm{sp01}$ & Traíra & Hoplias malabaricus & 80 & 20.33 & 15010 & 187.6 \\
\hline sp02 & Lambari & Astyanax fasciatus & 318 & 8.1 & 2825 & 8.9 \\
\hline sp03 & tambíu & Astyanax altiparanae & 141 & 6.4 & 907 & 6.4 \\
\hline sp04 & lambari & Astyanax sp. & 16 & 6 & 120 & 7.5 \\
\hline sp05 & pirambeba & Serrasalmus spilopleura & 6 & 11.4 & 378 & 63 \\
\hline sp06 & curimbatá & Prochilodus lineatus & 36 & 21.9 & 8797 & 244.4 \\
\hline sp07 & tuvira & Gymnotus carapo & 16 & 18.8 & 875 & 48.6 \\
\hline sp08 & rabo-de-rato & Eigenmannia virescens & 5 & 30.8 & 250 & 50 \\
\hline sp09 & caborja & Callichthys callichthys & 5 & 10.7 & 205 & 41 \\
\hline sp10 & caborja & Hoplosternum litoralle & 118 & 10.3 & 5820 & 49.3 \\
\hline sp11 & cadela & Acestrorhynchus lacustris & 111 & 14.9 & 4885 & 44 \\
\hline sp12 & saicanga & Galeocharax knerii & 10 & 12.5 & 410 & 41 \\
\hline sp13 & tabarana & Salminus hilarii & 11 & 15.9 & 790 & 71.8 \\
\hline sp14 & tilapia & Tilapia rendalli* & 12 & 11.3 & 1160 & 96.6 \\
\hline sp15 & cará & Geophagus brasiliensis & 53 & 11.2 & 2870 & 54.2 \\
\hline sp16 & bagre & Rhamdia cf. quelen & 38 & 11.2 & 1200 & 31.6 \\
\hline sp17 & mandi & Pimelodella sp. & 2 & 10 & 10 & 5 \\
\hline sp18 & mandi & Pimelodus maculatus & 2 & 12 & 10 & 5 \\
\hline sp19 & mandi & Iheringichthys labrosus & 24 & 14.2 & 930 & 38.8 \\
\hline sp20 & ximborê & Schizodon nasutus & 8 & 19.2 & 1505 & 188 \\
\hline sp21 & piapara & Leporinus obtusidens & 6 & 7.2 & 630 & 105 \\
\hline sp22 & canivete & Parodon nasus & 11 & 10 & 155 & 14 \\
\hline sp23 & lambe-lambe & Apareiodon piracicabae & 50 & 11.6 & 1335 & 26.7 \\
\hline sp24 & saguirú-branco & Steindachnerina insculpta & 60 & 33.9 & 837.5 & 14 \\
\hline sp25 & saguirú-curto & Cyphocharax modestus & 124 & 10.6 & 2926.6 & 23.6 \\
\hline sp26 & cascudo-viola & Rineloricaria latirostris & 11 & 13.9 & 115 & 10.4 \\
\hline sp27 & cascudo & Hypostomus margaritifer & 63 & 15.45 & 6578.5 & 104.4 \\
\hline sp28 & cascudo & Hypostomus ancistroides & 239 & 13.4 & 11962 & 50.1 \\
\hline sp29 & saguirú-comprido & Cyphocharax nagelli & 1 & 12.5 & 320 & 45.7 \\
\hline sp30 & carpa & Cyprinus carpio* & 1 & 27 & 530 & 530 \\
\hline sp31 & cadela & Oligosarcus paranensis & 13 & 12.1 & 215 & 16.5 \\
\hline sp32 & cascudo & Hypostomus sp.A & 7 & 13.5 & 415 & 59.3 \\
\hline sp33 & cascudo & Hypostomus sp.B & 26 & 18.3 & 3940 & 151.5 \\
\hline sp34 & cascudo & Hypostomus sp.C & 2 & 8.2 & 10 & 5 \\
\hline sp35 & cascudo-viola & Rineloricaria sp.A & 3 & 14.5 & 70 & 23.3 \\
\hline sp36 & sarapó & Sternopygus macrurus & 2 & 41.5 & 190 & 95 \\
\hline
\end{tabular}

*exotic species. 
eost fish. There is a positive and significant corrrelation $(\mathrm{r}=0.83, \mathrm{n}=13,0.05<\mathrm{p}<0.01$; Figure 2 ) between the number of families and the number of species of fish in each fishing site, indicating that the increase of the number of families results in richness increasing.

Two captured species are exotic: the tilapia Tilapia rendalli and the carp Ciprinus carpio. Although they presented comparatively low catches, they are fairly abundant along the Sorocaba river, mainly in the Ituparanga reservoir and in its urban stretches which cross the municipalities of Votorantim and Sorocaba. In the small tributaries where tilapias were released, they quickly became dominant.

Total number of fish species estimated by the jackknife method is $\mathrm{S} *=44$ (39-49, 95\% IC). Figure 3 displays the species abundance curve in decreasing order of importance by the Whittaker plot.

As usual it is constituted by few very abundant species and a series of species with intermediate abundance.

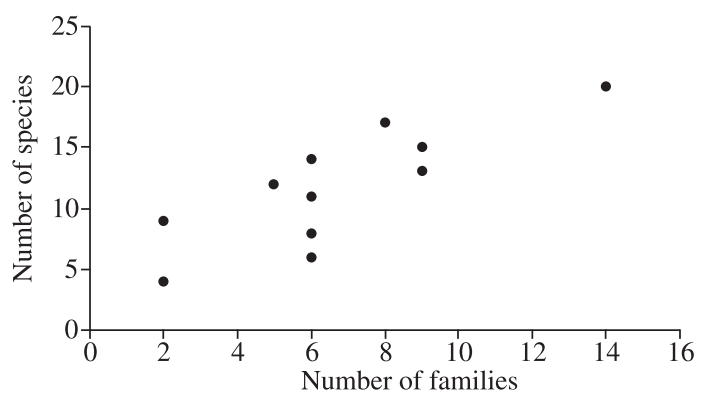

Figure 2. Scatterplot between the number of species and the number of families at each sampling site.
The most abundant species in the basin are Astyanax fasciaus (sp02), Hypostomus ancistroides (sp28), Astyanax altiparanae (sp03) and Cyphocharax modesta (sp25), intermediate species like Astyanax sp (sp04), Gymnotus carapo (sp07) and Oligosarcus paranensis (sp32), Tilapia rendalli (sp14) and Salminus hilarii (sp13) and rare species like Cyphocharax nagelli (sp29), Cyprinus carpio (sp30).

The adopted species-abundance model were the Logarithmic Series $\left(\chi^{2}=10.959<\chi_{0.05: 8}^{2}=15.51\right)$ and the truncated lognormal $\left(\chi^{2}=0.8733<\chi_{0.05 ; 6}^{2}=12.59\right)$. For the logarithmic the value of $\alpha$ was estimated as $\alpha=6.96$ (for $\mathrm{x}=0.9957, \mathrm{~S}=38, \mathrm{~N}=1628$ ). The truncated lognormal estimated $S^{*}=39.2$. Pooling all sampling sites and calculating the total diversity, values of diversity in numerical abundance and weight were almost the same (3.99 and 3.92, respectively). Analysing diversity in numerical abundance per site, so04, ip03, and sa01 showed the highest values. These sites are not well preserved considering the physico-chemical analysis (Smith and Petrere, 2000). Sites so03, pj01, rm01, pi01, and sa02 exhibited the lowest diversity values. According to the physico-chemical data, these sites are the most disturbed ones (Figure 4a).

Along the Sorocaba river (so01, so02, so03, and so04) there is an expected increasing diversity $\left(\mathrm{H}^{\prime}{ }_{\mathrm{N}}\right.$ and $\left.\mathrm{H}^{\prime}{ }_{\mathrm{W}}\right)$ gradient from its headstream to its mouth, with some low values due to pollution when crossing the municipalities of Votorantim and Sorocaba (so03). This same result repeats for some tributaries. The Ipanema River (ip01, ip02, and ip03) exhibits an increasing gradient (Figure 4a, 4b)

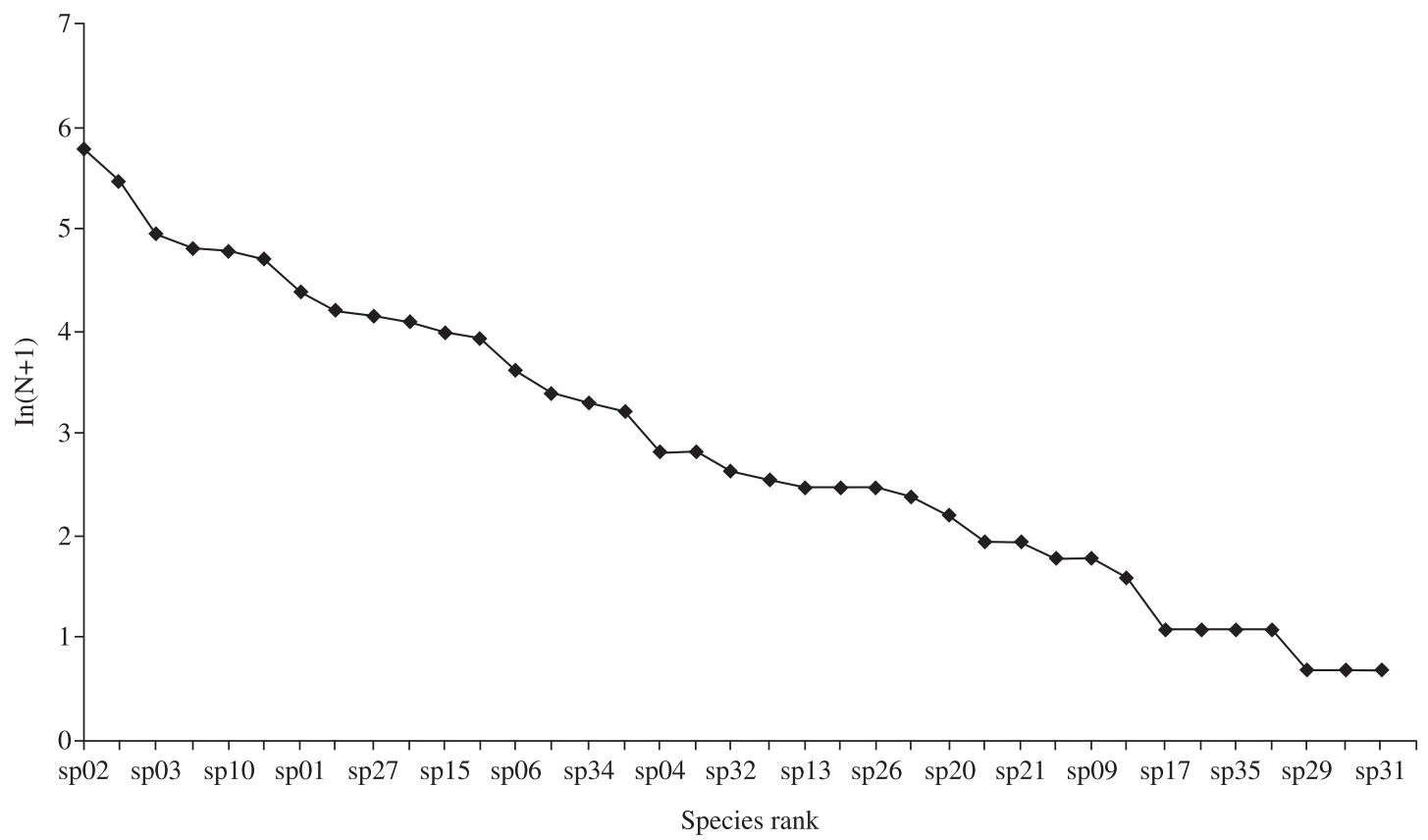

Figure 3. Whittaker plot of the fish collected in the Sorocaba river basin. N- number of individuals per species. 
along its reach. It was verified that the largest $\mathrm{H}^{\prime}{ }_{\mathrm{N}}$ takes place in little impacted and in dammed stretches.

\subsection{Diversity seasonal variation}

In general the numeric diversity was higher in the dry station $\left(\mathrm{H}^{\prime}{ }_{\mathrm{N}}=3.97\right)$ than in the rainy $\left(\mathrm{H}^{\prime}{ }_{\mathrm{N}}=3.62\right)$, 8 sampling sites presented larger indices in the dry period and 5 in the rainy period (Figure 5). The sites that presented larger diversity indices and their respective periods were: so04 (dry and rainy), sa01 (dry), so01 (dry), ip02 (dry) and ip03 (dry and rainy). There is variation of the diversity in the dry and rainy periods, being evident the similarities between the diversities in the two seasons. A diversity declining from sa01 to sa02 in both seasons can be seen probably due to the impact caused by sand extraction.

Another gradual fall may be seen from so01 to so03 and later an abrupt increment in so04 in the dry season. This effect can be attributed to the increasing impact due to domestic and industrial effluents in Rio Sorocaba from so01 to so03, water improving downriver. The higher diversity in the dry season may also be explained, as fish are more vulnerable due to water volume reduction.

Comparing the sampling sites relative to their diversities in relation to their respective richness and total
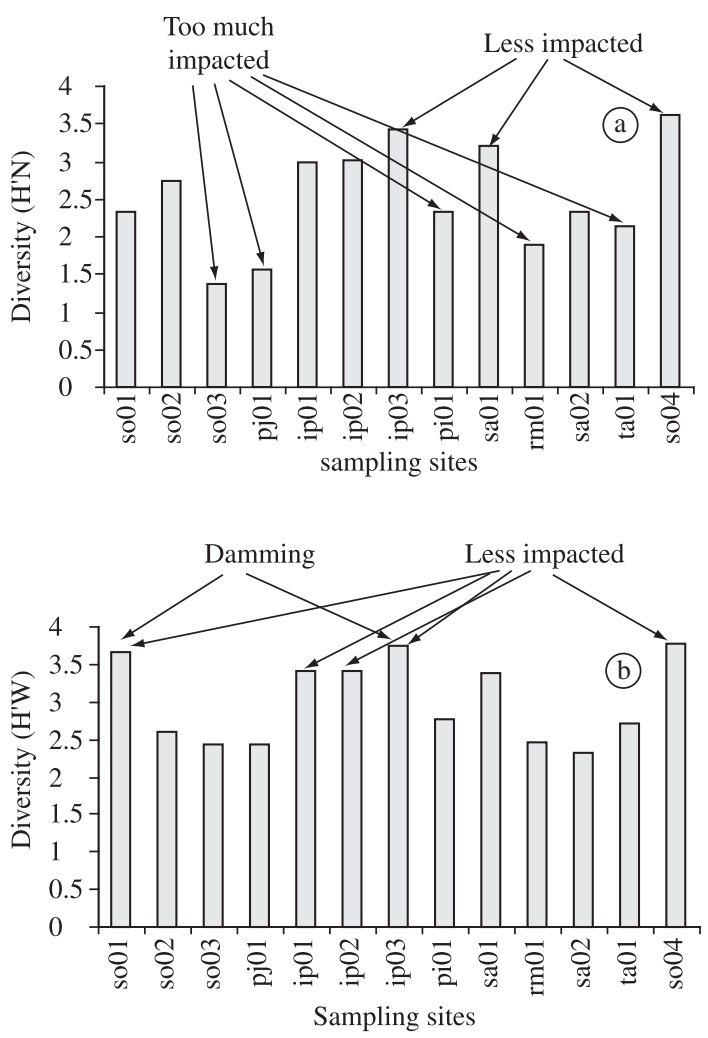

Figure 4. Shannon-Wiener diversity index calculated a) in numbers $\left(\mathrm{H}^{\prime}{ }_{\mathrm{N}}\right)$ and $\left.\mathrm{b}\right)$ in weight $\left(\mathrm{H}_{\mathrm{W}}{ }_{\mathrm{W}}\right)$ in each sampling site. abundance in each season, it is seen that those sites with larger diversity possess higher richness, but not always possess the largest abundances. On the other hand, sites with smaller diversities exhibit smaller richness and higher abundances. The higher abundance in those sites is due to the higher dominance, contrary to sites with high diversities. The paired $t$ test carried out with $\mathrm{H}^{\prime}{ }_{\mathrm{N}}$ and $\mathrm{H}^{\prime}{ }_{\mathrm{w}}$ between the two seasons were not significant (Figure 5).

\subsection{Sampling sites biotic classification according to their physical and chemical variables}

The clustering of the species abundance matrix (in number of individuals per species) in the sampling sites, combining the dry and rainy season data is shown in Figure 6. Its inspection shows 6 groups.

Group 1 is formed by sa02, ip03 and rm01 in the dry season and rm01 in the rainy season. In this group, the abundance of predator fish species is high, as with peixe-cadela (sp11-Acestrorhynchus lacustris) and traíra
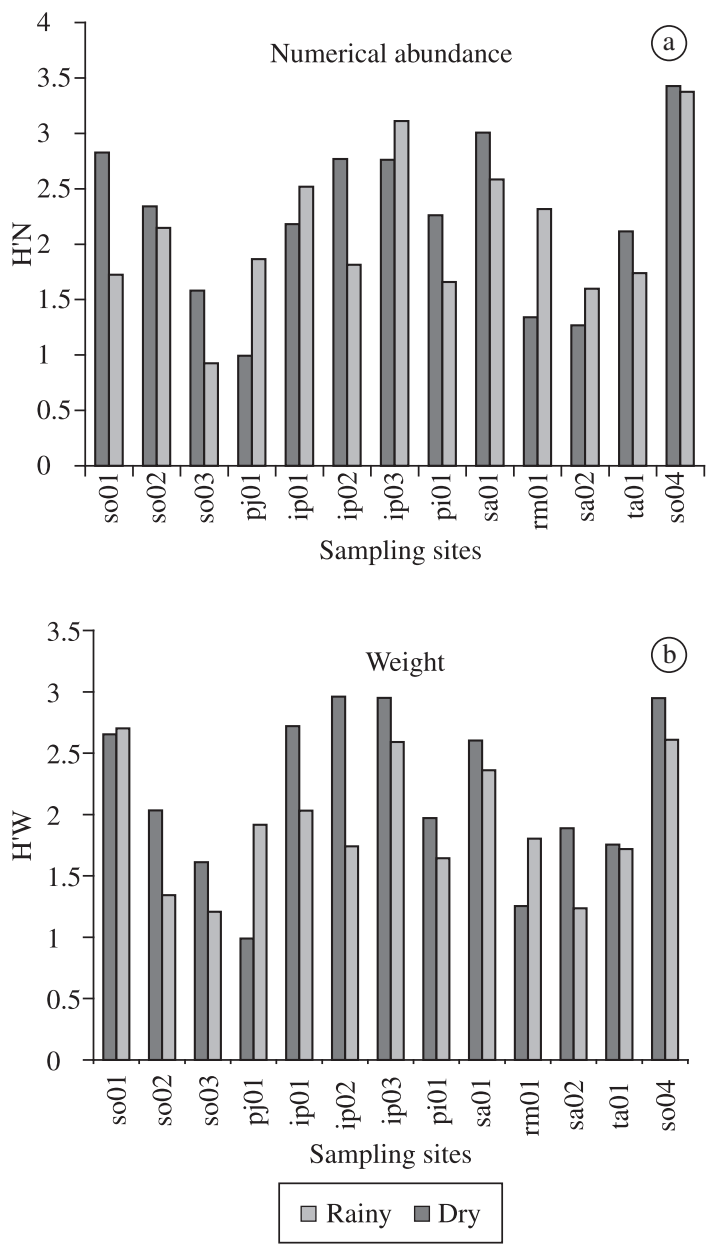

Figure 5. Seasonal variation of the Shannon-Wiener diversity index calculated a) in numbers $\left(\mathrm{H}_{\mathrm{N}}{ }^{\prime}\right)$ and $\mathrm{b}$ ) in weight $\left(\mathrm{H}_{\mathrm{w}}{ }\right)$ in each sampling site. 


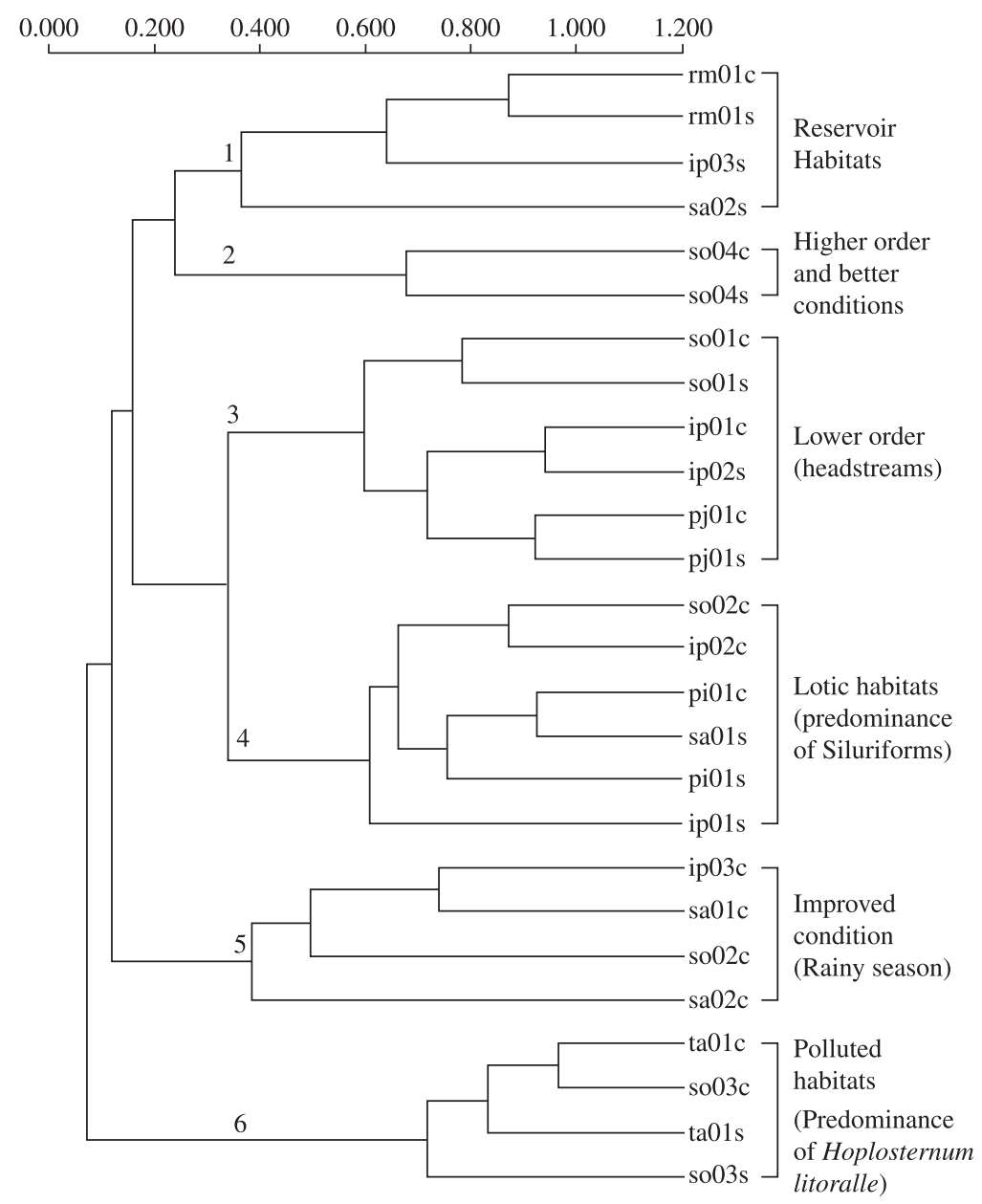

Figure 6. Dendrogram of sampling sites in the dry (S) and in the rainy season (C), grouped according to fish species numerical abundance $\left(\mathrm{r}_{\text {coph }}=0.82\right)$.

(sp01-Hoplias malabaricus), and armoured fishes. This group is composed of originally lotic sampling sites later dammed.

Group 2 is just constituted by so04 in the dry and rainy seasons. This site presented the highest richness, abundance and so higher diversity. Its fish fauna is mostly composed of traíra (Hoplias malabaricus), curimbatá (Prochilodus lineatus), tabarana (Salminus hilarii), armoured fish and characins. Just for holding so many species, this site presents low degradation and seems to possess several habitats. It is typically lotic with the largest stream order among the other sites. It is located just below Sorocaba city, after Rio Sorocaba received the largest effluent load. In view of its higher richness, it can be considered as a sort of recovering site.

Group 3 is formed by pj01, ip01, ip02 and so01 in the dry season and ip01, pj01 and so01 in the rainy season. They are of low order stretches characterised by the largest abundance of lambaris. The colonising success of Astyanax fasciatus in the Itupararanga reservoir should be emphasised. Besides, in Rio Pirajibu (pj01s and pj01c) there are favourable habitats for lambaris like dead logs and vegetation in spite of the strong water flow.

Group 4 is formed by ip01, sa01 and pi01 in the dry season and ip02, so02 and pi01 in the rainy season. There is a dominance of Siluriformes, where the most important genus is Hypostomus. There are other important species, such as the cará (Geophagus brasiliensis), traíra (sp01-Hoplias malabaricus), the lambaris (sp03Astyanax altiparanae and sp02-Astyanax fasciatus) and the saguirú (sp25-Cyphocharax modestus).

Group 5 is composed of the stations ip03, sa01 and $\mathrm{sa} 02$ in the rainy and so02 in the dry season, in stretches of middle order. They also presented high Siluriformes abundance, especially armoured fishes and other species typical in running water like the piapara (sp21-Leporinus obtusidens), canivete (sp22-Parodon nasus) and lambelambe (sp23-Apareiodon piracicabae). They are lotic habitats.

Group 6 is formed by so03 and ta01, inndistinctly in both seasons. In these sites there is the dominance of the 
caborja (sp10-Hoplosternum litoralle), typical of lentic habitats; so03 is a marginal pond.

Using the data and the cluster analysis from Smith and Petrere Jr. (2000), the Mantel test was applied using the numerical abundance matrix data and the abiotic variables. A low consistency between the two matrices is shown $(r=0.04 ; p=0.73)$ indicating that the distribution of the abundances of the species in the sampling sites is not related to the physical and chemical variables.

\section{Discussion}

According to Castro and Menezes (1998), there are 261 freshwater fish species in the state of São Paulo. According to Smith et al. (2003), the number of species known in the Sorocaba river basin is about 53. In this paper, we report a collection of 38 species. These values seem similar to the values estimated by the truncated lognormal. (39). These orders were also dominant in the Sorocaba River Basin. According to LoweMcConnell (1975), 58 fish families are estimated for South America also with the dominance of Siluriforms and Characiforms. In the state of São Paulo, especially in the Tiete River Basin, 25 families occur (Castro and Menezes, 1998). In the Sorocaba River Basin, 14 fish families are currently recognised, corresponding to $56 \%$ of the total known families for the state. Britski (1972) pointed out that most freshwater fishes in Brazil belong to the Characidae family.

Matthews (1998) mentions that for fish assemblages of temperate rivers, there are many species per family, with few families; the opposite is verified in tropical rivers. In the Sorocaba river basin, there are 14 families, some of these just with a single species, as is the case of the families Prochilodontidae, Serrasalmidae and Erythrinidae. The positive correlation detected in this paper, between the number of families and the number of species confirms the reasoning above. Matthews (1998) also points out that the success of the families in tropical rivers is due to the diversity of food, habitats and resources in general.

The spatial distribution of the fish fauna in this paper is in accordance to countless papers published in other basins of the Tietê river system. We can mention the papers of Caramaschi (1986) - Tietê, Castro and Arcifa (1987) in reservoirs, Barrella (1989) in the Jacaré Pepira a Tietê right margin affluent. Less demanding species regarding feeding and reproduction have wider geographical distribution like Hypostomus ancistroides, Astyanax fasciatus, Astyanax altiparanae, Geophagus brasiliensis and Cyphocharax modestus, being also considered the most abundant species in Sorocaba river basin. These species were already documented as being very common in rivers, streams and ponds of the state of São Paulo (Britski, 1972).

Castro and Arcifa (1987) showed the dominance of Cyphocharax modestus and Astyanax fasciatus in some reservoirs in the state of São Paulo, and the same oc- curs in Itupararanga reservoir (site so01). Besides the reservoir species, well adapted species Hypostomus ancistroides, Hypostomus margaritifer, Prochilodus lineatus, Leporinus striatus, Leporinus obtusidens, Schizodon nasutus and Apareiodon piracicabae are typical of lotic habitats.

Britiski (1972), Nomura (1984) and Uieda (1995) characterise the armoured fish of the genus Hypostomus as vegetarian inhabiting running waters. Nomura (1984) also describes the genus Apareiodon as preferential inhabitants of running waters. Here we emphasise the presence of curimbatá Prochilodus lineatus in marginal ponds (site so03), confirming that this migratory species live in still water utilising them as nurseries according to Godoy (1995), due to food availability, and sheltering even for pre-adults and adults (Agostinho et al., 2004).

Due to pollution and riparian deforestation, a decline in fish richness and diversity is verified in the Sorocaba river basin. This is evident in sites so02 and c so03 when compared to so01 close to the cleaner headstreams, in agreement with Bain et al. (1988) claiming that these impacts lead to diversity homogeneity. Siltation also reduces the biomass and the diversity of fish (Berkman and Rabeni, 1987).

The fish community trophic structure changes, reducing the relative abundance of benthonic insetivores and herbivores. Sedimentation increase also reduces the diversity of insects, degrades the spawning habitats, induces behavioural changes in fish spawning, increases egg mortality, decreasing larvae rate of growth, then affecting their development and survival (Berkman and Rabeni, 1987).

The fish community of the basin displays species abundance distribution with few very abundant species or rare and several of species with intermediate abundance, as commonly expected. Such a pattern is typical, being fitted by the truncated distribution lognormal. In our case, the truncated lognormal and the logarithmic series fitted to our data indicating that they are ripe, big, diversified and with great natural variety (Magurran, 1988; Tokeshi, 1993). According to Sheldon (1968), the lognormal model is the one that better fits to the distribution of abundance river fish species, followed by the logarithmic series. Gray (1987) suggests that the logarithmic series has been shown to be more appropriate when samples come from large communities. This model may also fit small samples of communities also adjusted for the truncated lognormal (Preston, 1948).

Most community data are adjusted by the truncated lognormal (Sugihara, 1980). May (1981) observed that when the lognormal is associated to undisturbed communities, it tends to be later replaced by the geometric series or logseries due to processes of organic pollution, which was not confirmed here. The lack of fit of the Brokenstick model in our data set is perhaps due mainly to the fact that this model predicts communities with high uniformity (May, 1975; Magurran, 1988), which is not the case here. 
Frontier (1985) suggests that the use of those models is a tool for the detection of disturbances in the ecosystem due to the pollution, where the faunistic changes are difficult to determine due to samoling variability. When communities are impacted by pollution, its drives away from the lognormal, but if this disturbance persists, it thends to returns to balance and again may follow the lognormal. The use of those models should be carried out with criteria and care, because these models involve very abstract and general hypotheses (Frontier, 1985). For the basin, $\mathrm{H}^{\prime}{ }_{\mathrm{N}}=4.011$ was obtained, while $\alpha$ is estimated by the logseries, which may also be taken as a diversity index of $\alpha=6.96$.

The numerical diversity for the whole data set indicated an increase in relation to a longitudinal pattern. Uieda and Barreto (1999), studying the Capivara river, a tributary of the Tietê river, obtained the same result, still indicating the increase of the diversity with the increase of river order. Testifying this sort of finding, there is an increase of species richness in the Sorocaba river (so01, so02, so03 and so04) and river Ipanema (stations ip01, ip02 and ip03). In Sorocaba river, there is a sequence of 13, 14, 6 and 18 collected fish species. The river Ipanema presented 13, 12 and 17 species, respectively.

As expected there was a species richness increase downriver. Marciano (2001) also detected a river order influence upon the community in affluents of the Sorocaba river. Such a fact is attributed to the increase of the area and consequently of the diversity of habitats (Vanotte et al., 1980; Bain et al., 1988; Matthews, 1998). Another relevant point is the diversity $\left(\mathrm{H}^{\prime}{ }_{\mathrm{N}}\right)$ and richness reduction in impacted sites, due to pollution, deforestation and siltation. This same result was detected by Marciano (2001). Industrial and domestic pollutants are the most impactant factors of the aquatic biota (Silveira and Sant'Anna, 1990), decreasing species richness, as was also documented by Costa et al. (1995) in the Billings reservoir, São Paulo. The deterioration of the aquatic habitats, due to pollution, acts directly upon the fish community structure, which are regarded as sensitive indicators of environmental alteration, when accelerated levels of impact are verified (Ribeiro, 1994; Smith et al. 1997).

The diversity in weight $\left(\mathrm{H}_{\mathrm{w}}{ }^{\mathrm{N}}\right)$ showed higher values in dammed and more preserved sites. In these sites, small sized species predominate. Such a fact is due to the dominance of some species, as for instance Hypostomus spB and Geophagus brasiliensis in so02, Hoplias malabaricus in so03 and rm01 and Acestrorhynchus lacustris in rm03. A similar result was also detected by Catella (1992) studying the fish assemblage of Baía da Onça in South Pantanal. Those places, besides being better preserved, present a more complex habitat structure such as the presence of macrpphytes (Smith and Barrella, 2000; Smith et al., 2003).

When comparing the two seasons, the numeric and weight diversities were not statistically different between the sampling sites along the basin. A similar result was also found by Marciano (2001). Beaumord and Petrere (1994) argue that the diversity similarity between the dry and rainy seasons is due to a small variation in the abundance of the resident species. In spite of no differences between the two seasons, higher numerical diversity was found in the dry season. Beaumord and Petrere (1994) also detected a similar result in the Manso river in the state of Mato Grosso. This may be due to a large statiblity during this period. Concerning species abundance distribution, sample sites were not separated according to seasons. Although habitat data were not collected in the present study, abundance distribution was defined according to habitat type (lotic and lentic), habitat size, and consequently to microhabitat availability.

Fish species composition and abundance differed among sampling sites. Lotic sites exhibited the predominance of Siluriforms, such as Hypostomus ancistroides and Pimelodus maculatus. Additionally, these sites are richer in microhabitats like dead logs, debris and rocks used as shelter, foraging, and spawning sites as pi01, pj01, so04, ip01, ip02, and ip03. Astyanax fasciatus, Astyanax altiparanae, Cyphocharax modestus and Steidachnerina insculpta occurred in high abundances at these sites. According to some authors, differences in species composition and abundance may be related to current velocity and river dimensions (Meffe and Sheldon, 1988), depth and type of substratum (Bain et al., 1988). In this way, habitat characteristics influence species composition and abundance, which seems to be explained by the ecomorphology. Species living in lotic habitats exhibit morphological traits that minimise current effect, enhancing their ability of occupying such habitats, increasing their abundance (Matthews, 1998).

Sites like so01 are predominantly lentic, exihibiting high sagüirus abundance and characins; ta01 and so03 present high abundance of Hoplosternum litoralle, typical fish of still waters. This species presented high abundance in more polluted sites such as so03 and ta01 and low abundances in more preserved ones like so01, ip01, ip02 and ip03, implying that it prefers more impacted habitats. This may be due to higher food abundance, absence of competitors and predators and accessory breathing exihibited by the species.

This may also explain the success of Hoplosternum litoralle to colonise low oxygen concentration with reduced water volume (Kramer et al., 1978; Matos et al., 1993). This species exihibits two traits: accessory breathing and parental care which may confer greater success when invading some habitats such as marginal lagoons.

In site rm01, a great number of predators were collected, such as traíra and peixe-cadela. The main reason is that this site results from a fall of a bridge, which reduced the water flow of Ribeirão dos Macacos, forming a slough. As a result, there is more food available to predators, such as foraging species hiding under the vegetation. According to Kushlan (1976), in more stable habitats predators are common, as they are poorly adapted to places under severe water fluctuation, as originally 
it was site rm01. As we may see this as a structuring fish community, predator pressure may be a major force in the process.

As we see, there are differences in the species distribution among the fishing sites along the same river, as occured in the rivers Sorocaba, Ipanema and Sarapuí. A probable explanation for this may be the existence of a physical gradient (Vanotte et al., 1980) associated the a mosaic of habitats in the riverbed as documented by Pringle et al., (1988), which will determine different species compositions and abundances along the river course.

According to the environmental conditions (Smith and Petrere, 2000), the sampling sites were divided in sites that receive a great amount of effluents, sites exhibiting recovering physico-chemical conditions in the rainy season, and those receiving low effluent discharge. However, our findings suggest that the physico-chemical variables did not influence the species abundance distribution along the sampling sites. According to Suzuki et al. (1997), the influence of limnological variables on the ichthyofauna is stronger in lentic habitats, where nutrient retention may occur in the water column by thermic stratification, causing physico-chemical alterations.

In contrast, in lotic habitats this phenomenon normally does not occur. The lack of correlation between physico-chemical variables with fish abundance distribution indicates that abundance may be regulated by habitat characteristics (e.g., substratum type, water velocity, river width, presence of dead logs, debris and rocks), which were taken into account in the present study. However, the influence of these factors on species abundance distribution was evidenced by the cluster analysis, as well as biotic interactions. Schlosser (1995) discusses the influence of habitat diversity and resources on the ichthyofauna; sites with several habitat types, which he named complementaries, support many fish populations compared to limited and distant sites. In addition, he showed that habitat heterogeneity is related to the ecotone waterearth interface, especially in riparian vegetation.

To Collares-Pereira et al. (1995), the water-earth interface is the region that congregates habitat heterogeneity, refuge availability and nutrients. According to these authors, large fishes prefer deeper sites covered by riparian vegetation and small fishes inhabit preferentially shallow sites covered by macrophytes. In brief, differences among sites habitats related to different abiotic gradients along the river, such as habitat diversity (Vannote et al. 1980; Johnson et al., 1995), influence of water velocity and river size (Meffe and Sheldon, 1988), depth and substratum type (Bain et al., 1988), and water-earth interface (Schlosser, 1995) influence fish spatial distribution. Quantitifying the resources, the shelter sites, food and habitats contributes to emphasising differences among sites, influencing fish community structure (Schreck and Moyle, 1990; Barrella and Petrere, 1994).

Biotic interactions such as predator-prey may have direct and indirect effects on fish community struc- ture (Winemiller, 1995). Such a fact was indicated by Smith and Petrere (2001) analysing the reservoir of Itupararanga. These authors evidenced the coexistence of some species with preferences for similar habitats besides the coexistence of predator-prey. The coexistence of species was also pointed out by the cluster analysis using the species abundance in the collection sites, showing the preference of certain species for specific habitats. As biological characteristics are more difficult to measure than physico-chemical ones (Barreto and Uieda, 1998), to date, few papers have been published in Brazil which would evaluate the importance of those characteristics in community structure and distribution.

Besides the existence of morphologic and physiologic characteristics, which could benefit some species like Hoplosternum litoralle in polluted sites, some species must go up river avoiding pollution (Gilbert, 1991). After a period in which a river or stream has been submitted to a given impact, fish return if conditions improve due to sewage treatment (Hassell et al., 1988; Gilbert, 1991; Wootton, 1990). Although it is already known that pollution unleashes a series of consequences for the fish community, we are still unable to determine accurately if regeneration is really possible, and how long it may take.

River rehabilitation is possible if the basin is faced as a whole. There are several studies showing that invaders are (more) successful in degraded habitats. But when the initial conditions are restored, the native species are more successful in re-occupying their historical habitats. Mark/recapture experiments would reveal subpopulation structure.

Fortunately, part of the sewage of the metropolitan area of Sorocaba is now being treated and water conditions are improving. But, we should point out that it is not enough, as the tribuatries should also be cleaned together with the preservation and recovery of the riparian forest, as well as the preservation of the meadows and marginal ponds.

Acknowledgements - The authors thank CNPq, FAPESP (proc. \#95/1311-0), and FNMA/FUNDUNESP (proc. \#046/95) for the financial support, PUC-SP, UNESP-Rio Claro, and USP-São Carlos also provided financial and logistical support. We are especially grateful to Dr. Luciano Bonatti Regalado for map drawing, Irieme Smith, Marcos César Rodrigues Senteio and Dr. Luciano Fogaça de Assis Montag for field assistance.

\section{References}

BAIN, MB., FINN, JT. and BOOKE, HE., 1988. Stream regulation and fish communnity structure. Ecology, vol. 69, no. 2, p. 382-392.

BARRELLA, W. and PETRERE JUNIOR, M., 1994. The influence of environmental factors on fish community structure in Jacaré Pepira river. In COWX, I. (Ed.). Rehabilitation of inland fisheries. Oxford: Fishing News Book. p.161-170.

BARRELLA, W., 1998. Alterações das comunidades de peixes nas bacias dos rios Tietê e Paranapanema (SP), devido a 
poluição e ao represamento. Rio Claro: UNESP. 115 p. [Tese de Doutorado].

BARRETO, MG. and UIEDA, VS., 1998. Influence of the abiotic factors on the ichthyofauna composition in different orders stretches of Capivara River, São Paulo State, Brazil. Verhandlungen Internationale Vereinigung Limnologie, vol. 26, p. 2180-2183.

BEAUMORD, AC. and PETRERE JUNIOR, M., 1994. Comunidade de pece del rio Manso, Chapada dos Guimarães, MT, Brasil. Acta Biologica de Venezuela, vol. 15, no. 2, p. 21-35.

BERKMAN, HE. and RABENI, CF., 1987. Effect of siltation on stream fish communities. Environmental Biology of Fishes, vol. 18 , no. 4 , p. $285-294$.

BRANCO, SM., 1972. Poluição e intoxicação de peixes. In Poluição e Piscicultura. São Paulo: Comissão Interestadual da Bacia Paraná-Uruguai. p. 45-52.

BRITSKI, HA., 1972. Peixes de água doce do Estado de São Paulo: sistemática. In Poluição e Piscicultura. São Paulo: Comissão Interestadual da Bacia Paraná-Uruguai. p. 83-108.

BRITSKI, HA., SATO, Y. and ROSA, ABS., 1984. Manual de identificação de peixes da bacia do São Francisco. Brasília: CODEVASF. p. 143.

CAMARGO, AFM., BINI, LM. and SCHIAVETTI, A., 1995. Avaliação dos impactos provocados pelas descargas de esgotos orgânicos em alguns corpos d'água do município de Rio Claro. Oecologia Brasiliensis I: estrutura e funcionamento e manejo de ecossistemas brasileiros. Rio de Janeiro. p. 395-405.

CARAMASCHI, EP., 1986. Distribuição da ictiofauna de riachos das bacias do Tietê e do Paranapanema, junto ao divisor de águas. (Botucatu, SP). São Carlos: Departamento de Ciências Biológicas, UFSCar. 245 p. [Tese de Doutorado].

CASTRO, RMC. and ARCIFA, MF., 1987. Comunidades de peixes de reservatórios do sul do Brasil. Revista Brasileira de Biologia $=$ Brazilian Journal of Biology, vol. 47, no. 4, p. $493-500$.

CASTRO, RMC. and MENEZES, NA. 1998. Estudo diagnóstico da diversidade de peixes do Estado de São Paulo. In CASTRO, RMC. (Ed.). JOLY, CA., BICUDO, CEM. (Org.). Biodiversidade do Estado de São Paulo, Brasil: síntese do conhecimento ao final do século XX. São Paulo: FAPESP. 71 p.

CATELLA, AC., 1992. Estrutura da comunidade e alimentação dos peixes da Baia da Onça, uma lagoa do Pantanaldo rio Aquidauana, MS. Campinas: UNICAMP. [Dissertação de mestrado].

COLLARES-PEREIRA, MJ., MAGALHÃES, MF., GERALDES, AM. and COELHO, MM. 1995. Riparian ecotones and spatial variation of fish assemblages in Portuguese lowland streams. Hydrobiologia, vol. 303, no. 1-3, p. 93-102.

COSTA, MP., CARVALHO, PSM., MARTINS, MC., FERNANDES, AJ., RODRIGUES, PF. and VARGASBOLDRINI, C., 1998. Contamination and community structure of fishes from Billings Reservoir, São Paulo, Brazil. In International Congress of Limnology. Stuttgart: Mitteilungen Internationale Vereinigung für theoretische und angewandte. Limnologie, vol. 26, no. 5, p. 2215-2219.
DIGBY, PGN. and KEMPTON, RA., 1987. Multivariate analysis of ecological communities. London: Chapman and Hall. 206 p.

FAUSH, KD., LYONS, J., KARR, JR. AND ANGERMEIER, PL., 1990. Fish communities as indicators of environmental degradation. American Fisheries Society Symposium, no. 8, p. 123-144

FRONTIER, S., 1985. Diversity and structure in aquatic ecosystem. Oceanography and Marine Biology: an Annual Review, no.23, p. 253-312.

GARUTTI, V. and BRITSKI, AH., 2000. Descrição de uma espécie nova de Astyanax (Teleostei: Characidae) na Bacia do alto do Rio Paraná e consederações sobre as demais espécies do gênero na bacia. Porto Alegre: Comunicações do Museu Ciência e Tecnologia. v. 13, p. 65-88. Série Zoologia.

GILBERT, OL., 1991. The ecology of urban habitats. London: Chapman and Hall. 369 p.

GODOY, MP., 1975. Peixes do Brasil sub-ordem CharacoideiBacia do Rio Mogi Guassu. Piracicaba: Franciscana. vol. 4, $848 \mathrm{p}$.

, 1995. Piracema: peixes brasileiros também tem história. In Anais de Etologia. Pirassununga. cap. 13, p. 3-19.

GRAY, JS., 1978. The structure of meiofauna communities. Sarsia, vol. 64, no. 4, p. 165-272.

HASSELL, JHV., REASH, RJ., BROWN, HW., THOMAS, JL. and MATHEWS JUNIOR, RC., 1988. Distribution of upper and middle ohio river fishes, 1973-1985: associations with water quality and ecological variables. Journal of Freshwater Ecology, vol. 4, no. 4, p. 441-458.

JOHNSON, BL., RICHARDSON, WB. and NAIMO, TJ., 1995. Past, present and future concepts in large river ecology. BioSciense, vol. 45, no. 3, p. 134-41.

JUNK, WJ., BAYLEY, PB. and SPARKS, RE. 1989. The flood pulse concept in river-floodplain systems. Canadian Journal of Fisheries and Aquatic Sciences, no.106, p. 110-127.

KRAMER, DL., 1978. Dissolved oxygen and fish behavior. Environmental Biology of Fishes, vol. 18, no. 2, p. 81-92.

KREBS, CJ., 1989. Ecological Methodology. New York: Harper and Row. 650 p.

KUSHLAN, JA., 1976. Environmental stability and fish community diversity. Ecology, vol. 57, no. 4, p. 821-825.

LOWE-MCCONNELL, RHL., 1975. Fish communities in tropical freshwaters. London: Longman. 337 p.

1987. Ecological studies in tropical fish communities. Cambridge: Cambridge University Press. 382 p.

MAGURRAN, AE., 1988. Ecological disversity and its measurement. London: Groom Helm. 179p.

MANLY, BJ., 1986. Multivariate statistical methods: a primer. London: Chapman and Hall. 281 p.

MARCIANO, FT., 2001. Estudo limnológico da bacia do rio Sorocaba (SP) e utilização do índice de integridade biótica da comunidade de peixes para avaliação ambiental. São Carlos: Centro de recursos hídricos e ecologia aplicada, USP. 89 p. [Dissertação de Mestrado]. 
MATOS, E., MATOS, P., OLIVEIRA, E. and AZEVEDO, C., 1993. Ultra estrutura da espermatogênese do Tamoatá Hoplosternum litoralle (Teleostei, Callichthydae) do rio Amazonas. Revista Brasileira de Zoologia, vol. 10, no. 2, p. $219-227$

MATTHEWS, WJ., 1998. Patterns in freshwater fish ecology. London: Chapman and Hall. 752 p.

MAY, RM., 1975. Paterns of species abundance and diversity. In CODY, ML. and DIAMOND, JM. (Ed.). Ecology and Evolution of Communities. Cambridge: Cambridge University Press. p. 81-120

MEFFE, GK. and SHELDON, AL., 1988. The influence of habitat structure on fish assemblage composition in Southeaastern Blackwater Streams. The American Midland Naturalist, vol. 120, no. 2, p. 225-240.

MORING, JR., EILER, PD., NEGUS, MT. and GIBBS, KE. 1985. Ecological importance of submerged pulpwood logs in a Maine Reservoir. Transation of the American Fisheries Society, no. 115 , p. 335-42.

NOMURA, H. 1984. Dicionário de peixes do Brasil. Brasília: Editerra. 482 p.

ODUM, EP. 1985. Ecologia. Rio de Janeiro: CBS Ind. Com. Ltda. $434 \mathrm{p}$.

PETESSE, ML., PETRERE JUNIOR, M., SPIGOLON, RJ., 2007. Adaptation of the Reservoir Fish Assemblage Index (RFAI) for assessing the Barra Bonita Reservoir (São Paulo, Brazil). River Research and Applications, vol. 23, no. 6, p. 1535-1467.

PRESTON, FW., 1948. The commonness, and rarity of species. Ecology, no. 29, p. 254-83.

PRINGLE, CM., NAIMAN, RJ., BRETSCHKO, G., KARR, JR., OSWOOD, MW., WEBSTER, JR., WELCOMME, RL. and WINTERBOURN, MJ., 1988. Patch dynamics in lotic systems: the stream as a mosaic. Journal of the North American Benthological Society, vol. 7, no. 4, p. 503-24.

RIBEIRO, MCLB., 1994. Conservação da integridade biótica das comunidades de peixes do Ribeirão Gama: Área de Proteção Ambiental (APA) Gama/ Cabeça de Veado, Brasília, DF. Rio Claro: UNESP. [Tese de Doutorado].

ROMESBERG, HC., 1984. Cluster analisys for researchers. Belmont: Liftime Learning Publications. p. 334.

SCHLOSSER, IJ., 1995. Critical landscape attibutes that influence fish population dynamics in headwater streams. Hydrobiologia, no. 303, p. 71-81.

SCHRECK, CB. and MOYLE, PB., 1990. Methods for fish biology. Maryland: American Fisheries Society. 684 p.

SHELDON, AL., 1968. Species diversity and longitudinal succession in stream fishes. Ecology, no. 49, p. 193-98.

SILVEIRA, SS. and SANT'ANNA, FSP., 1990. Poluição hídrica. In Meio ambiente: aspectos técnicos e econômicos. Brasília: IPEA/pnud. p. 57-83.

SMITH, WS., BARRELLA, W. and CETRA, M. 1997. Comunidade de peixes como indicadora de poluição ambiental. Revista Brasileira de Ecologia, no. 1, p. 67-71.
SMITH, WS. 1999. A estrutura da comunidade de peixes da bacia do rio Sorocaba em diferentes situações ambientais. São Carlos: USP. 121 p. [Dissertação de Mestrado].

SMITH, WS. and BARRELLA, W. 2000. The Ichthyofauna of the marginal lagoons, SP, Brazil: composition, abundance and effect of the anthropogenic actions. Revista Brasileira de Biologia = Brazilian Journal of Biology, vol. 52, no. 4, p. 627-640.

SMITH, WS. and PETRERE JUNIOR, M., 2000. Caracterização Limnológica da bacia de drenagem do rio Sorocaba, São Paulo, Brasil. Acta Limnologica Brasiliensia, vol. 12, no. 2, p. 15-27.

2001. Peixes em represas: o caso de Itupararanga. Revista Ciência Hoje, vol. 29, no. 170, p. 74-78

SMITH, WS., PETRERE JUNIOR, M. and BARRELLA, W., 2003. The fish fauna in tropical rivers: the case of the Sorocaba river basin, SP, Brazil. Revista de Biología Tropical, vol. 51, no. 3-4, p. 769-782.

SMITH, WS., 2003. Os peixes do rio Sorocaba: a história de uma bacia hidrográfica. SOROCABA: TCM. 163 p.

SNEATH, PHAA. and SOKAL, RR., 1973. Numerical taxonomy. San Francisco: Freeman. p. 813-819.

SUZUKI, HI., PAVANELLI, CS., FUGI, R., BINI, LM. and AGOSTINHO, AA., 1997. Ictiofauna de quatro tributários do reservatório de Segredo. In AGOSTINHO, AA. and GOMES, LC. (Ed.). Reservatório de segredo: bases ecológicas para o manejo. Maringá: Universidade Estadual de Maringá. p. $259-273$.

TOKESHI, M., 1993. Species abundance patterns and community structure. In BEGON, M. and FITTER, AH. (Ed.). Advances in ecological research, no. 24, p. 112-179.

UIEDA, VS., 1995. Comunidade de peixes de um rio litorâneo: composição, habitat e hábitos. Campinas: UNICAMP. p. 229. [Tese de Doutorado].

UIEDA, VS. and BARRETO, MG., 1999. Composição da ictiofauna de quarto trechos de diferentes ordens do rio Capivara, Bacia do Tietê, Botucatu, São Paulo. Revista Brasileira de Zoociências, vol. 1, no. 1, p. 55-67.

VANNOTE, RV., MINSHALL, GW., CUMMINS, KW., SEDELL, JR. and CUSHING, CE., 1980. The river continuum concept. Canadian Journal of Fisheries and Aquatic Sciences, no. 37 , p. $130-137$

WARD, JV. and STANFORD, JA., 1989. Riverine ecosystems: the influence of man on catchmente dynamics and fish ecology. In DODGE, DP. (Ed.). Proceedings of International Larger River Symposium (LARS). Ottawa: Canadian Special Publication Fisheries Aquatic Species. p. 56-64.

WELCOMME, RL., 1979. Fisheries ecology of floodplain rivers. New York: Longman. p. 313.

, 1985. River fisheries. FAO Fisheries Technical Paper, vol. 262 , no. 1,330 p.

WOOTTON, RJ., 1990. Ecology of Teleost Fishes. London: Chapman and Hall. 404p. 